\title{
Microscopic and Physicochemical Evaluation of Leaves of Sphaeranthus indicus Linn
}

\author{
Sonia Singh ${ }^{* 1}$, Bhupesh Chander Semwal', Gurulingappa S Neeli ${ }^{2}$
}

\section{Sonia Singh ${ }^{* 1}$, Bhupesh Chander Semwal ${ }^{1}$, Gurul- ingappa S. Neeli \\ 'Department of Pharmacognosy, Institute of Pharmaceutical Research GLA University $17 \mathrm{Km}$ Stone, NH Mathura-Delhi Road, P.O. Chaumuhan Mathura, INDIA. ${ }^{2}$ Department of Pharmacognosy and Phytochemistry, K.L.E.S's College of Pharmacy Belgaum -590010 Karnataka, INDIA. \\ Correspondence \\ Sonia Singh*, Department of Pharma- cognosy, Institute of Pharmaceutical Research GLA University $17 \mathrm{Km}$ Stone, NH\#2 Mathura- Delhi Road, P.O. Chaumuhan Mathura, INDIA. \\ Email: sonia.singh@gla.ac.in \\ History \\ - Submission Date: 16-08-2016: \\ - Review completed: 30-08-2016; \\ - Accepted Date: 05-09-2016.}

DOI : 10.5530/pj.2017.1.4

Article Available online

http://www.phcogj.com/v9/i1

\section{Copyright}

(C) 2016 Phcog.Net. This is an openaccess article distributed under the terms of the Creative Commons Attribution 4.0 International license.

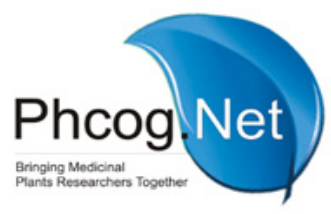

\begin{abstract}
Objective: To study the pharmacognostic characters of a medicinally important crude drug, Sphaeranthus indicus Linn. Methods: Various pharmacognostic parameters involved in organoleptic, microscopic, physicochemical, phytochemical and fluorescence evaluation were carried out. Results: The macroscopy study showed that the leaves was observed as sessile, obovate-oblong apex, tapered base, dentate margin, simple, serrate lamina, surface glabrous. The leaf microscopy showed the presence of diacytic stomata, unicellular covering trichomes, arc shaped vascular bundle which contain lignified xylem and non lignified phloem, cortical parenchyma and a thin strip of collenchyma, micro rosette calcium oxalate crystals. The powder characteristics of leaf showed the presence of lignified fibers, medullary rays, bordered pitted xylem vessels, calcium oxalate crystals, stomata, epidermal cells and covering trichomes. Physicochemical parameters like total ash value was $9.21 \%$, water soluble ash $1.56 \%$, acid insoluble ash $1.35 \%$, swelling index $4 \mathrm{~mL}$, loss on drying $1.09 \%$ and foreign matter was $0.20 \% \mathrm{w} / \mathrm{w}$ respectively where as stomatal indexes of upper and lower surfaces were 33.2 and 23 , respectively. The phytochemical screening revealed the presence of carbohydrates, flavonoids, alkaloids, volatile oil, fats and oils, tannins and phenolic compounds. Conclusion: The present study provides the scientific data for the proper authentification and establishment of quality control standards for the therapeutic use of Sphaeranthus indicus.

Key words: Histochemical evaluation, Organoleptic evaluation, Phytochemcial screening, Sphaeranthus indiucs.
\end{abstract}

\section{INTRODUCTION}

Sphaeranthus indicus Linn. is commonly known as "Mundi" and "East Indian globe-thistle, belongs to the family Asteraceae. It is a spreading aromatic herb, occurring at Rater of Chhindwara District, M.P and in the moist damp places of tropical zones of Garhwal Himalaya. ${ }^{1-3}$ It is a annual, aromatic herb having lanceolate, wing toothed leaves with semi-amplexicaul base, acutely serrate margin. ${ }^{4}$ The herbs contain a deep cherry coloured essential oil , a bitter alkaloid Sphaeranthine..$^{5}$ It also contain eudesmenolide-7a-hydroxy eudesm-4-en-6, 12-olide, 2-hydroxycostic acid, $\beta$-eudesmol, ilicic acid, methy chavicol, $\alpha$-ionone, $\mathrm{d}$-cadinene, $\alpha$-terpinene, citral, geraniol, geranyl acetate, sphaerene, indicusene and sphaeranthol. ${ }^{6,7}$ A paste of the herb mixed with oil is good in painful swellings and pruritus. ${ }^{1}$ The herb is used as a fish-poison and it is stuffed into holes of crabs to kill them. ${ }^{8}$ The root is reported as acrid, bitter and sweet in taste and highly efficacious as diuretic, febrifuge, expectorant and stomachic. It is also useful in strangury, diabetes, leprosy, fever, cough, pectoralgia, cough, gastropathy, hernia, haemorrhoids, helminthiasis and dyspepsia. The oil prepared from root is useful in scrofula. ${ }^{1}$ The root bark are grounded into powder and mixed with whey, is a valuable remedy in bleeding piles; also used as paste for local application. ${ }^{5}$ The powdered leaves are good for skin diseases and are considered as a nervine tonic. $^{1}$

The current literature revealed some pharmacognostical, physicochemical, phytochemical and pharmacological studies. The main objective of this study is to provide some valuable information with respect to its identification and standardization of $S$. indicus leaf which could be helpful in authenticity, purity and quality aspects.

\section{MATERIALS AND METHODS}

\section{Plant collection}

The fresh leaves of $S$. indicus Linn. were collected from the local areas of Hoshangabad, M.P and authenticated by Dr. R.S. Goudar, Dept. of Botany, R.L. Science Institute, Belgaum. A voucher specimen was preserved in the herbarium (RLI/Bot/06-07) for further reference. After authentication, the leaves of $S$. indicus Linn. were dried at room temperature
Cite this article : Singh S, Semwal BC, Neeli GS. Microscopic and Physicochemical Evaluation of Leaves of Sphaeranthus indicus Linn. Pharmacog J. 2017; 9(1):21-26. 
until they were free from the moisture and subjected to botanical, physicochemical and histochemical studies.

\section{Chemicals and instruments}

Phloroglucinol, hydrochloric acid, glycerin, iodine solution and all other chemicals used in the study were of analytical grade.

\section{Organoleptic evaluation}

The fresh leaves of S.indicus were subjected to morphological studies, compromised of organoleptic characteristics viz. colour, odour, taste, shape, texture were examined as per standard WHO guidelines. ${ }^{9}$

\section{Microscopical evaluation}

A histochemical and microscopical study of the fresh drug and powdered drug was performed according to the method described by Kokate ${ }^{10}$ and Khandelwal. ${ }^{11}$

\section{Physicochemical evaluation}

The shade dried leaves were subjected to size reduction to get fine powder (\#40 size mesh) and then evaluated for extractive value, loss on drying, swelling index, total ash value, acid insoluble ash value, water soluble ash value and fluorescence analysis as per literature. ${ }^{10,11}$

\section{Preparation of the extracts}

About $300 \mathrm{~g}$ of powdered plant material was subjected to successively hot continuous extraction with petroleum ether, n-hexane, chloroform and methanol. Finally, the marc was macerated with chloroform water for 24 hours to obtain the aqueous extract. Each extract were concentrated by distilling off the solvent and then evaporated to dryness on the water bath. The percentage yields of the extracts obtained were calculated in terms of the air-dried weight of the plant material. The color and consistency of the extracts were also noted. ${ }^{10}$

\section{Preliminary phytochemical evaluation}

Preliminary phytochemcial screening was carried out using the standard method mentioned by Kokate. ${ }^{10}$

\section{RESULTS}

\section{Organoleptic evaluation}

S.indicus was an annual herb. The leaves were sessile, prostrate, obovateoblong apex, tapered base, dentate margin, simple, serrate lamina, glabrous surface. The size of leaves varied from 1.5 to $4.5 \mathrm{~cm}$ (l) and 2.5 $\mathrm{cm}$ (b). The upper surface of leaf showed dark green colour while inner surface showed light green colour with characteristic odour and pungent taste (as shown in Figure 1).

\section{Mircoscopical and Histochemical evaluation}

Transverse section of leaf showed a dorsiventral pattern. The lamina consisted of upper epidermis, mesophyll and lower epidermis. The upper epidermis was single layered with more or less rectangular cells. The mesophyll was differentiated into palisade and spongy parenchyma. The palisade layer consisted of single layered elongated and compact cells. The spongy parenchyma layer was divided into five to eight layered cells, loosely arranged with inter cellular spaces. The lower epidermis was similar to upper epidermis.

The epidermal layers of lamina were continued in the midrib region. The strips of collenchyma were appeared just below the upper epidermis and above the lower epidermis, which was followed by cortical parenchyma. A well developed arc shaped vascular bundle was seen in the centre of midrib region. The vascular bundle was surrounded by parenchymatous bundle sheath. Xylem cells (lignified) were seen on the upper region whereas phloem (non lignified) was seen towards the lower side of the epidermal cells. The surface preparation showed the presence of diacytic stomata and covering trichomes on both surfaces of leaf, more along the midrib region. The covering trichomes were lignified unicellular as well as uniseriated multicellular blunt tip with a bulbous base. Transverse section of leaf was shown in Figure 2

\section{Powdered analysis}

The leaf powder is light green in colour, with a characteristic odour and pungent taste.

Histochemical evaluation of powdered drug showed lignified elongated fibers, lignified xylem vessels with pitted border, rosette type of calcium oxalate crystals and covering trichomes .as shown in Figure 3.

\section{Physicochemical evaluation}

The physiochemical parameters were shown in Table 1, such as total ash value was $9.21 \%$, water soluble ash $1.56 \%$, acid insoluble ash $1.35 \%$, swelling index $4 \mathrm{~mL}$, loss on drying $1.09 \%$ and foreign matter was $0.20 \% \mathrm{w} / \mathrm{w}$ respectively where as stomatal indexes of upper and lower surfaces were 33.2 and 23, respectively. The \% yield of Petroleum ether extract was $1.2 \% \mathrm{w} / \mathrm{w}, \mathrm{n}$-hexane extract $1.8 \% \mathrm{w} / \mathrm{w}$, chloroform extract $8.24 \% \mathrm{w} / \mathrm{w}$, methanol extract $40 \% \mathrm{w} / \mathrm{w}$ and aqueous extract $33.3 \% \mathrm{w} / \mathrm{w}$. The fluorescence analysis observed in visible, short and long ultra violet was mentioned in Table 2.

\section{Preliminary phytochemical screening}

Preliminary phytochemical screening revealed the presence of carbohydrates, flavonoids, alkaloids, volatile oil, fats and oils, tannins and phenolic compounds, mentioned in Table 3.

\section{DISCUSSION}

Standardization of crude drug is an essential tool for evaluating the purity, quality and efficacy of a drug. Morphological evaluation is helpful in the authentification of crude drug by evaluating the external appearance ie colour, shape, texture, size, odour, taste and so on. Microscopic

\begin{tabular}{cccc} 
Table 2: Fluorescence analysis of powdered leaves of S.indicus \\
\hline Reagents & Visible & $\begin{array}{c}\text { Short ultra } \\
\text { violet }\end{array}$ & Long ultra violet \\
\hline Petroleum ether extract & Green & Green & Dark green \\
n-hexane extract & Green & Green & White \\
Chloroform extract & Light green & Green & Off white \\
Methanol extract & Dark brown & Brown & White \\
Aqueous extract & Brown & Off white & White \\
$50 \%$ sulphuric acid & Brown & White & Dark brown \\
$50 \%$ nitric acid & Brown & Brown & Dark brown \\
$50 \%$ hydrochloric acid & White & Brown & Brown \\
$50 \%$ sodium hydro oxide & White & Light brown & Brown \\
\hline
\end{tabular}




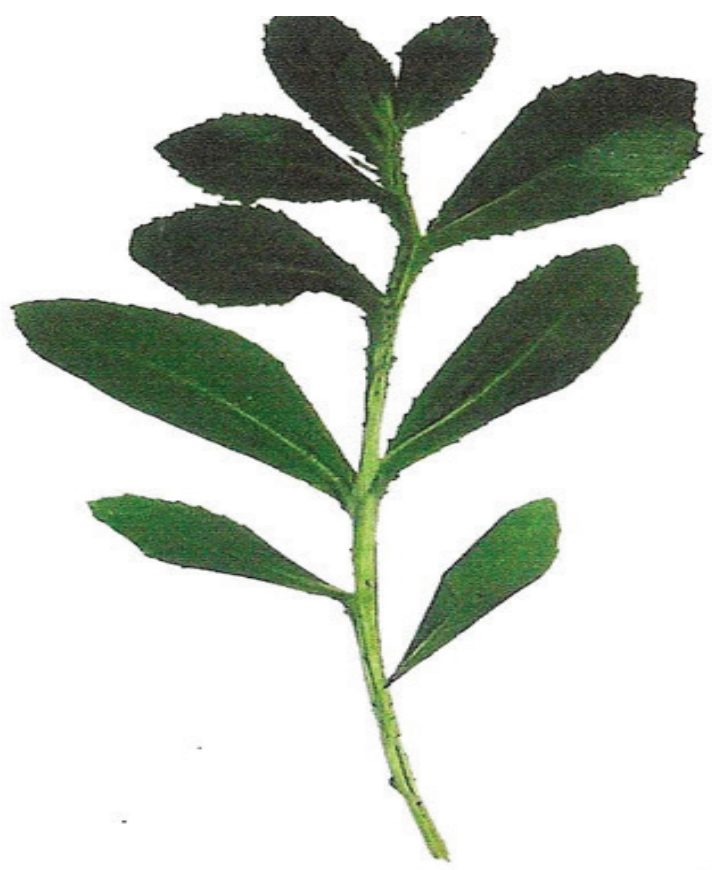

\begin{tabular}{cc} 
Table 1: Physicochemical evaluation of S. indiucs Linn. leaf \\
\hline Extractive Value & Colour \& Consistency $\quad \%$ Yield w/w \\
Petroleum ether & Greenish green semisolid viscous $1.2 \% \mathrm{w} / \mathrm{w}$ \\
n-hexane & Greenish green semisolid viscous $1.8 \% \mathrm{w} / \mathrm{w}$ \\
Chloroform & Greenish yellow semisolid viscous $8.24 \% \mathrm{w} / \mathrm{w}$ \\
Methanol & Reddish brown semisolid viscous $40 \% \mathrm{w} / \mathrm{w}$ \\
Aqueous & Brownish red semisolid viscous $33.36 \% \mathrm{w} / \mathrm{w}$ \\
Loss on drying & $1.09 \%$ \\
Ash value & $9.21 \%$ \\
Total ash value & $1.35 \%$ \\
Acid insoluble & $1.56 \%$ \\
Water soluble & $4 \mathrm{~mL}$ \\
Swelling index & $0.20 \% \mathrm{w} / \mathrm{w}$ \\
Foreign matter & Upper surface: 33.2 \\
Stomatal index & Lower surface: 23 \\
\hline
\end{tabular}

Figure 1: Sphaeranthus indicus Linn. leaf

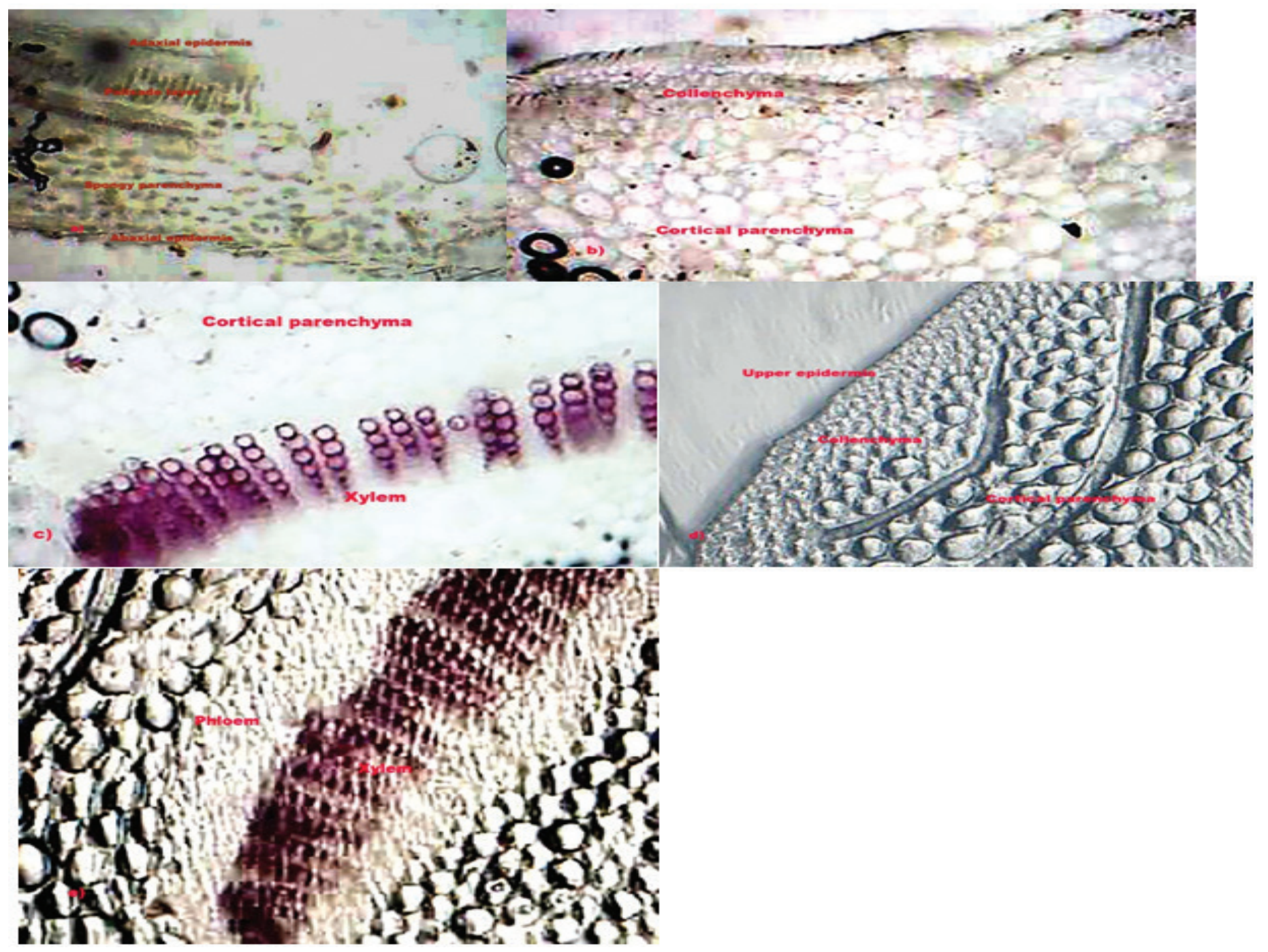

Figure 2: Microscopical characteristics of S. indiucs leaf. 


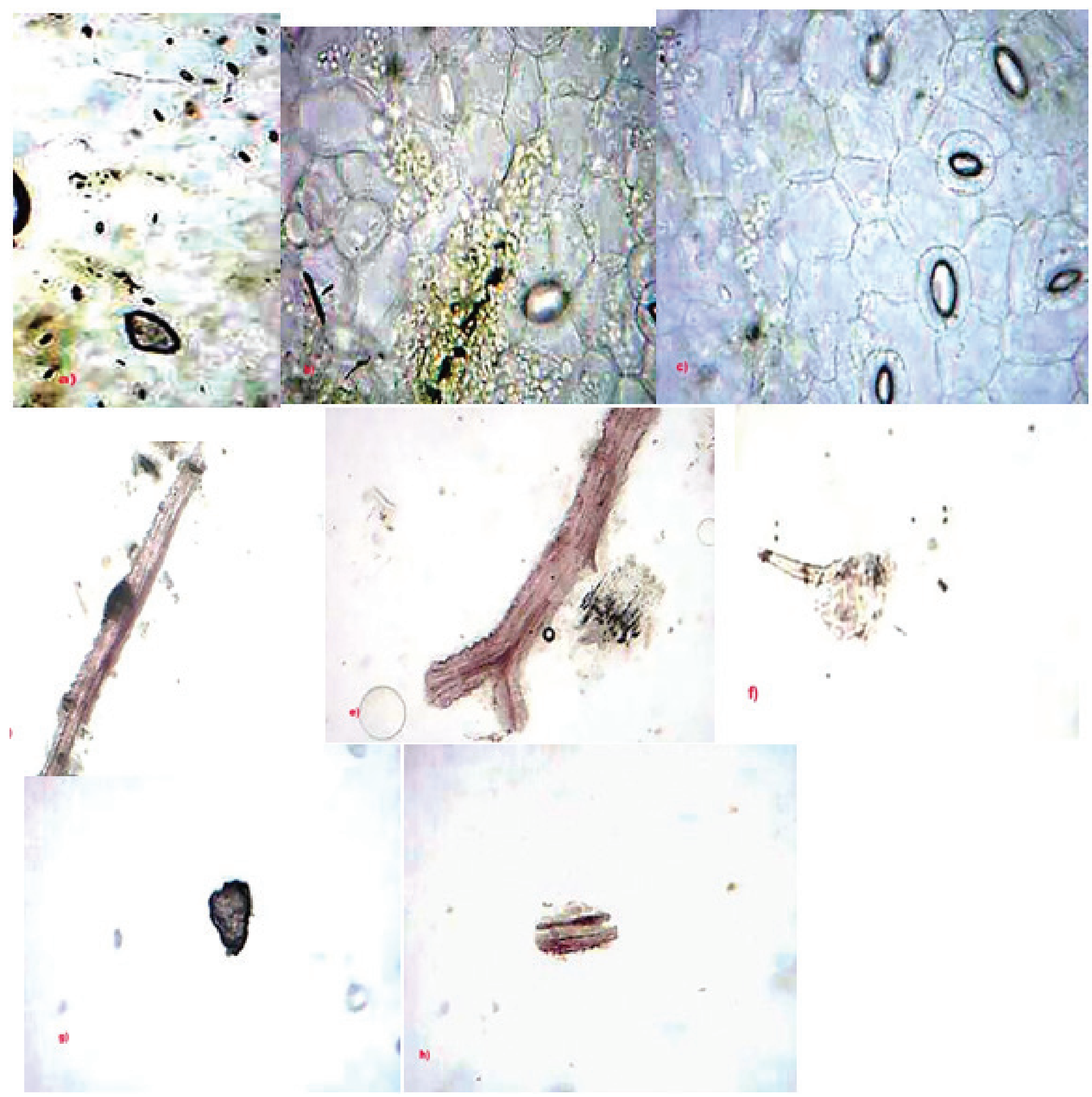

Figure 3: Histochemical characteristics of leaf powder of S.indicus (a) stomata (in 10x)(b) epidermal cells (c) diacyctic stomata (in 45x)(d)lignified fibers (e) medullary rays (f) covering trichomes (g) rosette type calcium crystal (h) xylem vessel. 
Table 3: Preliminary Phytochemical screening of S. indicus Linn. leaf extract

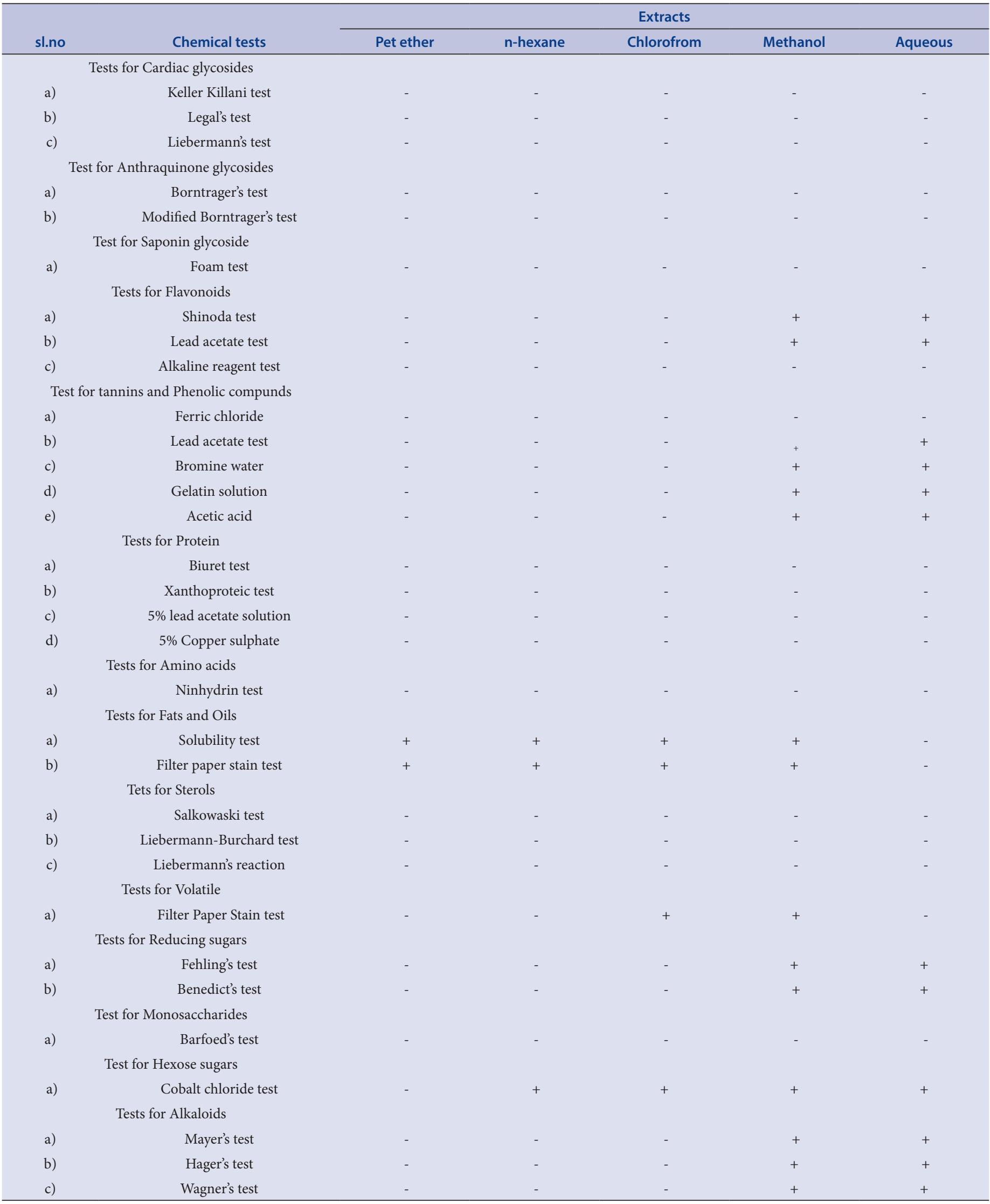


analysis of a crude drug is necessary for the quantitative identification of closely allied and adulterants/substituents present in crude drug which can be distinguished by using optical microscopy. Even, identifying the powder characteristics of crude drugs is useful in authentification of drug and identification of the adulterants. The physicochemical parameter such as ash value, extractive value, swelling index, foaming index and fluorescence analysis will be helpful in identification and authentification of the plant material. The preliminary phytochemical screening will reveals the presence of chemical constituents in the crude drug.

In conclusion, the present work was undertaken to lay down the standardization parameter which reveals the authenticity, purity and quality of this medicinally crude drug.

\section{ACKNOWLEGEMENT}

None

\section{CONFLICT OF INTEREST}

Nil

\section{REFERENCES}

1. Arya VS. Indian Medicinal Plants. Chennai: Orient Longman Ltd. 180;1997.

2. Bhattacharjee SK. Handbook of Medicinal Plants. Jaipur: Pointer Publishers. 328; 1998.

3. Kirtikar KR, Basu BD. Indian Medicinal Plants. Dehradun: International Book Distributors. 1347;1999.

4. Pandey G. Dravyaguna Vijnana. Varanasi: Krishnadas Academy Orient Publishers \& Distributors. 616-7; 2001.

5. Nadkarni AK. The Indian Materia Medica. Mumbai: Bombay popular Prakashan Pvt. Ltd. 1162-3;2002.

6. Rastogi RP, Mehrotra BN. Compendium of Indian Medicinal Plants. New Delhi: Publications and Information, CSIR. 690;1993.

7. Rastogi RP, Mehrotra BN. Compendium of Indian Medicinal Plants. New Delhi: Publications and Information, CSIR . 384;1993.

8. Ramachandran K, Shri. Kashyapa K, Shri Chand R. The useful plants of India. New Delhi: Publications and Information Directorate, CSIR. 591;1994.

9. WHO. Quality control methods for medicinal plant material. Geneva: WHO. 22-34;1992.

10. Kokate CK. Practical Pharmacognosy. New Delhi: Vallabh Prakshan. 135-6;1986.

11. Khandelwal KR. Practical Pharmacognosy. Pune: Rachana Enterprises. 157$9 ; 2002$.

Cite this article : Singh S, Semwal BC, Neeli GS. Microscopic and Physicochemical Evaluation of Leaves of Sphaeranthus indicus Linn. Pharmacog J. 2017; 9(1):21-26. 